

Jurnal Bina Praja 8 (1) (2016): 69-81

Jurnal Bina Praja

e-ISSN: 2503-3360 | p-ISSN: 2085-4323

Accreditation Number

735/AU2/P2MI-LIPI/04/2016

http://jurnal.kemendagri.go.id/index.php/jbp/index

\title{
Participation and Neutrality of State Civil Apparatus in Direct REgiOnal ELECTION: SuRABaya City CaSe
}

\author{
Catur Wibowo Budi Santoso ${ }^{1, *}$ \\ ${ }^{1}$ Research and Development Agency, Ministry of Home Affairs (BPP Kemendagri) \\ Jl. Kramat Raya No. 132, Senen, Jakarta Pusat
}

Received: 23 February 2016; Accepted: 30 April 2016; Published online: 31 May 2016

\begin{abstract}
In relation to the existence of State Civil Apparatus, at least there are two issues that must be observed in the implementation of Regional elections, namely the issues of participation and neutrality of State Civil Apparatus. The phenomenon that occurs during this time is the involvement of the State Civil Apparatus in attendance is still minimum (low). Moreover, it is believed that there are many Civil Apparatus State who is not neutral in the organization of Regional Elections. In this regard, this study aims to analyze the participation and neutrality of State Civil Apparatus. The method utilized in this study is qualitative. The result of the study shows that in general the participation of State Civil Apparatus in Surabaya is adequately good, but the neutrality of State Civil Apparatus has not implemented well enough. There are at least three (3) main factors influencing the participation of Civil State Apparatus, namely the factors of leadership exemplary, commitment to employees, and employee development. As for the neutrality of the State Civil Apparatus, among others, is influenced by the factors of the ambition of employee, primordialism, and working environment of employees.
\end{abstract}

Keywords: bureaucracy, participation, neutrality.

\section{INTRODUCTION}

In the present era of globalization, there is a tendency for change in politics and paradigm of democracy, that is, from representative democracy to direct democracy. Indeed, the implementation of democracy could be done with two (2) ways, namely, representative democracy that puts the people's representatives in parliament (DPR and DPRD) or through parliamentary democracy as well as direct democracy. The implementation of Regional Elections (Pemilukada) directly as a form of direct democracy is a step forward in the democratization that has been built since the 1998 reformation era in Indonesia. On of the fruits of reformation in the government area is a direct election (Thoha, 2003). The implementation of direct election is an important moment to get better local leaders. In addition, direct Regional Election is a demand that must be implemented for the sake of learning democracy.

For the first time in Indonesia, Direct General Election was conducted simultaneously in 2015 .
This policy will have positive benefits. There is the efficiency of budget, time, and effort because it can simultaneously select regional leaders in the regions (Widodo, 2015). The principle of this policy is trying to do more equitable democratization simultaneously, so that the odds of schemings can be minimized because when the election is not held simultaneously, then outsiders can interfere. But, if done simultaneously, it also will carry major implications in terms of security. If there is an unwanted thing, then the attention to security will spread.

Actually, the simultaneous Regional Elections (Pemilukada) are not much different from the election that has happened so far. Simultaneous Regional Elections equalize and facilitate the process of directing, coordinating, leading, and controlling than the partial election. Concretely, this simultaneous election wants a coherent policy.

The simultaneous elections in 2015 were held on December 9, 2015, which were to choose 269 regional leaders consisting of nine governors,

\footnotetext{
* Corresponding Author

Phone : +6281315345149

Email : caturbpp@gmail.com
} 
224 regents, and 36 mayors. Specifically for East Java Province, there were 26 pairs of candidates of regents and mayors registering for simultaneous Regional Elections to the office of the General Elections Commission (KPU) respectively in the region until the second day of the registration period, including Regional Elections (Pemilukada) in Surabaya City. Until the closing of the second day, July 27 at 16:10 pm, as many as 26 pairs of candidates submitted their registration documents. In East Java, the total of 19 elections was held simultaneously on December 9, 2015 (Anam, 2015).

In relations to the existence of the State Civil Apparatus (State Civil Apparatus), there are at least two (2) issues that must be anticipated in the implementation of Regional Elections, including the General Election in Surabaya City, namely the issue of State Civil Apparatus's participation and the issue of State Civil Apparatus's neutrality.

The studies on the neutrality of civil servants in Regional Elections, among others, were by Yamin (2012) on the neutrality of civil servants in Regional Election in Takalar District, Purba (2010) on the neutrality of civil servants in direct Regional Elections, Kumaryanto (2013) on the analysis of judicial neutrality of civil servants in direct Regional Elections, Sriwahyuni (2006) on the neutrality of civil servants in direct Regional Elections, and Ritan (2005) on the neutrality of the bureaucracy in the elections of regional leaders and regional vice-leaders. All these studies only discussed the neutrality of civil servants without discussing their participation.

The result of the previous research or study is that the bureaucracy neutrality on Regional Election in Surabaya City, which showed that the involvement of bureaucracy on the administration of Regional Elections was undeniable because there is an opportunity with the issuance of Circular Note of the Ministry of Administrative and Bureaucratic Reforms No. SE/08.A/M.PAN/5/2009 that allows the bureaucrats to be the members of PPK, PPS, and KPPS so that the involvement of civil servants in Regional Elections is clear, which means that bureaucrats are getting more knowledgeable and feeling more certain as well as not wavered or afraid to be the members of Committee on the process of Regional Elections. The neutrality of bureaucrats, whose main job and their working territory are outside KPU of Surabaya City and do not have any administrative relations with KPU in the city on the administration of Regional Elections, shows a very low neutrality based on the case and phenomena that happened according to the statement of the informants (Kadir, 2010). The study only focused on the neutrality of bureaucracy, while this study aside from focusing on the neutrality of bureaucracy is also examining the participation of bureaucrats in
Regional Elections.

According to Jer (2015), State Civil Apparatus's involvement in voters' participation is still minimum (low). For example, the result of research conducted by the research institute of Syarif Kasim (Suska) Islamic University (UIN) on Legislative Election and the 2014 Presidential Election in Pekanbaru City, among professions, State Civil Apparatus was the lowest on the participation. Therefore, it is feared that in the future administration of the Regional Election, this will happen again. So, apparently State Civil Apparatus turned out to be the laziest to come to the polling stations. While in fact, State Civil Apparatus is the most knowledgeable and got the most information about Regional Election. This becomes a challenge for us all, especially in 2015 Regional Elections in.

Furthermore, from the aspect of State Civil Apparatus's neutrality, past experience has shown that during the Old Order (1950-1965), the rise and fall of the cabinet had an impact on employment stability. During the New Order (1966-1997), civil servants were used as a political tool to maintain power. And at the Reformation era, civil servants were feared as a tool of politics. The impact of civil servants' non-neutrality is that the role and function of civil servants as a means of unifying, servants and government administrators not running well, discrimination in services, civil divisions, conflict of interest, and no longer professional civil servants.

The implementation of Election is often exploited by a handful of people by involving Civil Servants. Although prohibited by any regulations, the phenomenon is difficult to get rid of and even tends to be worse. The issue then makes a number of parties propose a regulation prohibiting State Civil Apparatus not to have the rights to vote, just like Indonesian Military/Indonesian Police. Because, as long as the rights to vote is not regulated, it is believed that the neutrality of civil servants will remain a source of trouble in General Election.

According to Wihdatiningtyas (2015), civil servants' strong involvement that happens in Regional Elections is difficult to avoid. The existing regulations have not been effective in preventing the violation from occurring. Throughout the rural areas, almost all found the same problem. Therefore, the suggestion that civil servants are prohibited in politics is also stated by civil servants, and it could be a consideration.

Civil Servants' involvement is not always sweet in the result. For civil servants with losing candidates, they will be transferred or moved to places deemed unsuitable. For example, there was once a Regional Secretary who was transferred to the staff in the district because it supports candidates who were lost in the General Election. It is like gambling. If a candidate supported by the Civil 
Servants wins, the career of the Civil Servants could skyrocket. Instead, civil servants with defeated candidate, must be ready to suffer. Many complaints from civil servants who express that neutrality are very difficult to implement, because if they do not support one candidate in the Regional Election, then their career as civil servants will also stagnate. This means that many of them were not neutral because of "compulsion".

Whereas, the neutrality of State Civil Apparatus in the implementation of Regional Elections has simultaneously been governed by Law 5/2004 of the State Civil Apparatus and Law No. 23/2014 on Regions. Those two Government Law have been firmed to sanction those who do not obey. Even, Article 70 Paragraph (1) Letter a and b of Law No. 8/2015 on Regional Elections, expressly forbid the State Civil Apparatus and village leaders to be involved in the winning of candidates in the elections. In addition, the Government Regulation No. 53 of 2010 on Civil Servants Discipline explains that every civil servant must maintain neutrality in elections, such as they can not be in the succeeding team, campaign team, or just words of support for regional leader candidates who will participate in the regional elections.

In order to put into realization the State Civil Apparatus's neutrality and to ban the use of government assets in the Regional Elections in December 2015, previously the Minister of Administrative and Bureaucratic Reforms had issued a circular letter, namely Circular Note of the Minister No. B/2355/M.PAN-RB/07/2015 of July 22,2015 . The letter stated that sanctions would be applied to all State Civil Apparatus involved in the organization the campaign in any form, from moderate to severe penal sanctions. Sanctions are in the form of promotional delay, performance benefits delay, salary increase delay, and up to honorable and dishonorable dismissal. In addition to the circular, Minister of Administrative and Bureaucratic Reforms has also issued Letter No. B / 3235 / M.PANRB / 10/2015 and Letter No. B / 3236 / M.PANRB / 07/2015 to ask all of Personnel Development Officers to maintain neutrality, as well as monitoring the neutrality of the State Civil Apparatus, the implementation of the basic values, codes of conduct and codes of conduct of State Civil Apparatus in simultaneous Regional Elections.

However, it can not guarantee that there is no longer support of civil servants in Regional Elections to be utilized a number of parties because it has the potential to gain big enough votes. This means that civil servants may take advantage of their authority to be able to "mobilize" and intimidate people to support one candidate, although they are not part of the campaign team of regional leader candidates.

The rationality "whence for" on the urgency to examine the participation and neutrality of State Civil Apparatus in the implementation of Regional Elections us based on the above phenomenon. The issue of State Civil Apparatus's low participation rates and the "partiality" of State Civil Apparatus in Regional Elections must found its way out as soon as possible in order to bring out policies to increase the participation of State Civil Apparatus in Regional Election and prevent partiality of State Civil Apparatus in the Regional Elections in Surabaya.

Based on the above focus, the subject matter of this study is the problem or phenomenon of State Civil Apparatus's low participation rates and the "partiality" State Civil Apparatus in Regional Elections. The formulation of the problem in this study related to the subject matter are: (1) To what extent State Civil Apparatus's participation in the organization of the Regional Election in Surabaya City?, (2) Is the State Civil Apparatus neutral in the organization of the Regional Election in Surabaya City?, (3) What factors are affecting the participation and the neutrality of State Civil Apparatus in the organization of the Regional Election in Surabaya City?, and (4) What are the policies that need to be done to improve and maintain the neutrality and the participation of State Civil Apparatus in the organization of the Regional Election in Surabaya City?

In accordance with the subject matter of the study above, the objectives of this study are: (1) Determining the level of State Civil Apparatus's participation in the organization of the Regional Election in Surabaya City; (2) Knowing State Civil Apparatus's neutrality in the organization of the Regional Election in Surabaya City; (3) Identifying the factors that affect participation and neutrality State Civil Apparatus in the implementation of the General Election in Surabaya; and (4) formulating policies that need to be conducted to improve and maintain the neutrality and the participation of State Civil Apparatus in the organization of the Regional Election in Surabaya City.

There are some major theoretical references required in the activities of this study. First, the policy on the establishment of State Civil Apparatus (State Civil Apparatus). In Law No. 5/2014 on State Civil Apparatus, describes matters related to the existence of State Civil Apparatus, among others is that the employee of State Civil Apparatus serves as an element of the state apparatus. As the element of the state apparatus, he implements the policies set by government institution leaders and must be free from the influence and intervention of all groups and political parties (Prasojo, 2005).

Second, State Civil Apparatus's participation in Regional Elections. The political participation of bureaucracy/State Civil Apparatus is the involvement of a group that serves as the state 
apparatus/government at the lowest to the highest level in the political system (Rourke, 2009). To demonstrate the consistency of the implementation of the constitution values both in Rechtstaat conception or rule of law, the legal rules of positive law then give the concrete form of the legality of bureaucratic political participation as a good participant in the election (Fischer and Sirianni, 2007; Henry, 2004).

Due to their quite huge potential, then State Civil Apparatus are expected to participate in Regional Elections. Some of the participation can be done by State Civil Apparatus in Regional Election are as follows: (1) State Civil Apparatus must be neutral towards political party, (2) State Civil Apparatus must be active in being smart and wise voters, (3) State Civil Apparatus take part in dissemination and conveying information of Regional Elections, both in their family circle and their residential area, (4) State Civil Apparatus take part as campaign team of the government to create a conducive general election condition, (5) State Civil Apparatus become the members of PPK, PPS, and KPPS with the permission of their direct leaders, and (6) the support of State Civil Apparatus in the secretariat of Regional KPU in PPK, and in PPS to organize the stages of Regional Elections (Saputro, 2013).

The participation or involvement of State Civil Apparatus in succeeding the stages of Regional Election will create the construction of State Civil Apparatus's image that is neutral and professional as well as shows the effort to build people's trust on the motto of State Civil Apparatus as State Servants and Community Servants. So, it is expected that State Civil Apparatus participate or play an active role in succeeding the organization of Regional Elections. The employees that have big potential invite the people in their residential area to use their voting rights. Each State Civil Apparatus is expected to be the exemplary for the community to use their voting rights, and not to abstain (Stoner, 2010; Sutarto, 2012). As Community Servant, ASIN has a responsibility to success the Regional Elections so that it can run safely, peacefully, and with quality.

Third, the neutrality of State Civil Apparatus in Regional Election. Neutrality comes from the word neutral that means pure (Echols and Shadily, 2011). Pure, in this case, is equalized to not partial. In this context, the definition of neutral at least related to 4 (four) meanings, namely: (1) Non-Partial attitude and not partial to one group/class, (2) not discriminative, (3) sterile from group interest, and (4) not influenced by the interest of political parties (Chakim, 2013).

In regards to the existence of State Civil Apparatus, then the neutrality of State Civil Apparatus is intended to avoid classification, conflict of interest, and discrimination in service. In addition, also to ensure State Civil Apparatus as the adhesive to the nation's unity in the framework of the Republic Indonesia, including as one of the pre-conditions to increase the professionalism of civil servants. This non-neutrality of bureaucracy or State Civil Apparatus must be avoided, so that it will have impact towards the role and function of State Civil Apparatus as the uniting tool, servant, and the government administrator not running, discrimination of service, division of bureaucracy or State Civil Apparatus, conflict of interest, and bureaucracy or State Civil Apparatus is no longer professional (Riggs, 2008).

Fourth, the factors that influence the neutrality of State Civil Apparatus in Regional elections. The reason State Civil Apparatus is not neutral in the direct regional election is very diverse. But in general the cause comes from internal and external factors of the State Civil Apparatus (Kuncoro, 2007), namely: (1) Internal Factor/from the inside of the civil servants (interest, ambition, primordialism, lack of confidence, and lack of solidarity among civil servants), and (2) External Factor/from the outside of the civil servant (habit, provocation, promises, weak supervision, and law regulation). Then, there are many factors that become the obstacle in seeking for politically neutral bureaucracy (State Civil Apparatus) and serve the community equitably and based on common interest (Pradhanawati, 2005), namely: political factor, bureaucracy system factor, and socio-culture factor.

Furthermore, based on the descriptions above, it was determined the analyzed aspects of participation and neutrality of the State Civil Apparatus in the election, namely:

1. The participation aspect of the State Civil Apparatus in the Regional Election in Surabaya City, including: (a) the impartiality of State Civil Apparatus against political parties, (b) the activeness the State Civil Apparatus to be intelligent and wise voters, (c) participation of State Civil Apparatus in socializing and information sharing about the Regional Election, both in the family environment and surrounding neighborhood, (d) the participation of State Civil Apparatus as the government campaigner to create an atmosphere of conducive Regional Election, (e) the membership of State Civil Apparatus in PPK, PPS, and KPPS with the permission of the immediate supervisor, and (f) the support of State Civil Apparatus in the Regional Election Commission secretariat, PPK, and PPS to carry out the stages of the election.

2. The neutrality aspect of State Civil Apparatus in the Regional Election in Surabaya City, including: (a) the attitude of State Civil Apparatus that is 


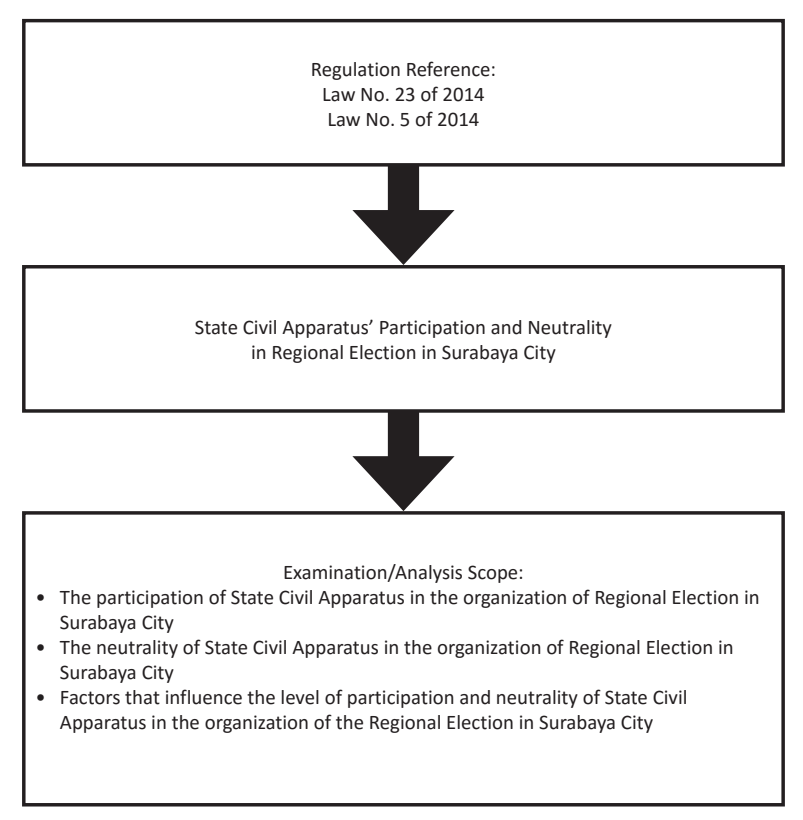

Figure 1. Study Flow of Thinking

impartial and not partial to one of the groups/ classes, (b) non-discriminative State Civil Apparatus, (c) State Civil Apparatus are sterile for group interest, (d) State Civil Apparatus are not affected by political party interest, (e) State Civil Apparatus do not violate their authority for their interest in the Regional Election, and (f) State Civil Apparatus do not use state facility.

\section{METHOD}

Due to the limitation of time (only 1 month for this study), the energy, budget and so that this study becomes deeper, then the study will only be conducted in 1 (one) provincial area, namely East Java Province (Surabaya City). The selection of this location is conducted as purposive, with the consideration that Surabaya City is one of the regions with a quite big number of State Civil Apparatus so that the participation and neutrality of State Civil Apparatus need to be examined on the organization of the Regional Election. In addition, Surabaya City is one of the Regions on the organization of the 2015 simultaneous Regional. The study uses the naturalistic method or qualitative with a descriptive explanation. According to Whitney (2000), descriptive research or study is the seeking of facts with right interpretation.

Data collecting in this study uses the method of (1) documentation, (2) interview, (3) FGD. There are two (2) types of data collected, the primary data and secondary data. Primary data is obtained from direct interviews with the competent parties in the organization of the Regional Election in Surabaya City. Meanwhile, secondary data is obtained from the literature /documentation review and supporting data relevant to this study sourced from related institutions in the organization of the Regional Election in Surabaya City. In accordance with both data collection methods used above, the assessment instruments or tools used in the data collection in this study are: (1) checklist/document analysis, (2) an open interview guidance, and (3) guidelines for FGD. The informants in this research are the competent parties in the organization of Regional Election in Surabaya City, namely National and Political Unity Agency apparatus, Election Commission officials, BKD, Inspectorate, and Election Supervisory Committee in Surabaya City. The type of data in this study is qualitative data and quantitative data. The method of processing and analysis of data used is a descriptive method, which is described in words.

\section{RESULT AND DISCUSSION}

\section{A. Description of Political Party and State Civil Apparatus in Surabaya City}

The number of political parties in Surabaya City can be seen in Table 1 . There are 8 (eight) factions in Regional House of Representatives (DPRD) in Surabaya City for the period of 20142019. The faction with the most number is PDIP

Table 1.

Faction of Regional House of Representatives (DPRD) in Surabaya City in 2014-2019

\begin{tabular}{lcc}
\multicolumn{1}{c}{ Faction } & $\begin{array}{c}\text { Number } \\
\text { of } \\
\text { Members }\end{array}$ & Head \\
$\begin{array}{l}\text { Faction of Indonesian Democrat- } \\
\text { ic Party of Struggle (F-PDIP) }\end{array}$ & 15 & Sukadar \\
\hline $\begin{array}{l}\text { Faction of Democratic Party } \\
\text { (F-PD) }\end{array}$ & 6 & Junaedi \\
\hline $\begin{array}{l}\text { Faction of People's Conscience } \\
\text { Party, National Democrats Party, } \\
\text { United Development Party } \\
\text { (F-HANDAP) }\end{array}$ & 6 & Naniek \\
\hline $\begin{array}{l}\text { Faction of Great Indonesia } \\
\text { Movement Party (F-Gerindra) }\end{array}$ & 5 & Zulfiani \\
\hline $\begin{array}{l}\text { Faction of National Awakening } \\
\text { Party (F-PKB) }\end{array}$ & 5 & Laila Mufidah \\
\hline $\begin{array}{l}\text { Faction of Prosperous Justice } \\
\text { Party (F-PKS) }\end{array}$ & 5 & Aksyad \\
\hline $\begin{array}{l}\text { Faction of Functional Groups } \\
\text { Party (F-Golkar) }\end{array}$ & 4 & Puyanto \\
\hline $\begin{array}{l}\text { Faction of National Mandate } \\
\text { Party (F-PAN) }\end{array}$ & 4 & Pertiwi Ayu \\
\hline
\end{tabular}

Source: Election Supervisory Committee of Surabaya City, 2015 
Table 2.

Leadership of the Regional House of Representatives (DPRD) in Surabaya City 2014-2019

\begin{tabular}{ccl} 
Position & Name & \multicolumn{1}{c}{ Political Party } \\
Chairman & Armudji & $\begin{array}{l}\text { Indonesian Dem- } \\
\text { ocratic Party of } \\
\text { Struggle }\end{array}$ \\
\hline Vice Chairman & Ratih Retnowati & Democratic Party \\
\hline Vice Chairman & Dharmawan & $\begin{array}{l}\text { Great Indonesia } \\
\text { Movement Party }\end{array}$ \\
\hline Vice Chairman & Masduki Toha & $\begin{array}{l}\text { National Awaken- } \\
\text { ing Party }\end{array}$ \\
\hline
\end{tabular}

Source: Election Supervisory Committee of Surabaya City, 2015

Faction (15 members), while the factions with the least numbers are Golkar Faction and PAN Faction (respectively only 4 members).

The leadership of the Regional House of Representatives (DPRD) in Surabaya City consists of 1(one) chairman and 3 (three) vice chairmen from political parties with the most vote in the council, as stated in Table 2.

For the Regional Election in Surabaya in 2015, there are 6 (six) political parties against Tri Rismaharini. At least there are six political parties, namely Democratic Party (PD), Great Indonesia Movement Party (Gerindra), Functional Groups Party (Golkar), Prosperous Justice Party (PKS), National Mandate Party (PAN), and National Awakening Party (PKS) are together united in Majapahit Coalition to support alternative candidate to defeat the incumbent duet of Surabaya Mayor Tri Rismaharini and the Vice-Mayor Whisnu Sakti Bhuana.

Majapahit coalition which has 29 chairs or 58 percent of parliament openly compete against the candidate of incumbent duet supported by Indonesian Democratic Party of Struggle (PDIP) which has 15 chairs. Meanwhile, People's Conscience Party (Hanura) with 3 chairs, National Democratic Party (NasDem) with 2 chairs, and United Development Party (PPP) with 1 chair, the total of 6 chairs, until now have not got closer to one of the supporting parties because they are still projecting the power map.

Furthermore, the number of Civil Servants/ State Civil Apparatus in Surabaya City can be seen in Table 3.

The data in Table 3 shows that Surabaya City has the most number of State Civil Apparatus if compared to other districts/cities in East Java Province (18.613 people). This means that there are 18.613 people that will attend the simultaneous Regional Elections on December 9, 2015 (If all with the ID Cards of Surabaya City).
Table 3 .

The Number of Civil Servants/State Civil Apparatus in East Java Province, 2015

\begin{tabular}{|c|c|c|c|}
\hline \multicolumn{4}{|c|}{$\begin{array}{c}\text { The Number of Civil Servants/State Civil Apparatus According } \\
\text { to Genders and District/City } \\
\text { East Java Province, } 2015\end{array}$} \\
\hline \multirow[t]{2}{*}{ District/City } & \multicolumn{2}{|c|}{$\begin{array}{c}\text { Civil Servants/State Civil } \\
\text { Apparatus }\end{array}$} & \multirow[t]{2}{*}{ Total } \\
\hline & Male & Female & \\
\hline \multicolumn{4}{|c|}{ District } \\
\hline Pacitan & 5128 & 3982 & 9110 \\
\hline Ponorogo & 6934 & 5679 & 12613 \\
\hline Trenggalek & 5.384 & 4.810 & 10.194 \\
\hline Tulungagung & 6.841 & 7.519 & 14.360 \\
\hline Blitar & 5.507 & 6.102 & 11.609 \\
\hline Kediri & 6.384 & 6.544 & 12.928 \\
\hline Malang & 8.437 & 7.950 & 16.387 \\
\hline Lumajang & 5.637 & 4.173 & 9.810 \\
\hline Jember & 9.532 & 7.379 & 16.911 \\
\hline Banyuwangi & 7.916 & 5.423 & 13.339 \\
\hline Bondowoso & 6.346 & 4.205 & 10.551 \\
\hline Situbondo & 5.102 & 3.548 & 8.650 \\
\hline Probolinggo & 5.993 & 4.199 & 10.192 \\
\hline Pasuruan & 6.495 & 6.299 & 12.794 \\
\hline Sidoarjo & 6.781 & 8.163 & 14.944 \\
\hline Mojokerto & 5.724 & 5.270 & 10.994 \\
\hline Jombang & 5.923 & 5.696 & 11.619 \\
\hline Nganjuk & 6.232 & 6.103 & 12.335 \\
\hline Madiun & 4.691 & 4.944 & 9.635 \\
\hline Magetan & 5.065 & 5.453 & 10.518 \\
\hline Ngawi & 7.006 & 6.196 & 13.202 \\
\hline Bojonegoro & 6.446 & 5.175 & 11.621 \\
\hline Tuban & 5.886 & 5.058 & 10.944 \\
\hline Lamongan & 7.073 & 5.281 & 12.354 \\
\hline Gresik & 4.911 & 5.023 & 9.934 \\
\hline Bangkalan & 5.547 & 4.701 & 10.248 \\
\hline Sampang & 4.983 & 3.223 & 8.206 \\
\hline Pamekasan & 5.392 & 3.411 & 8.803 \\
\hline Sumenep & 7.978 & 3.408 & 11.386 \\
\hline \multicolumn{4}{|c|}{ City } \\
\hline Kediri & 3.426 & 3.249 & 6.675 \\
\hline Blitar & 1.970 & 2.149 & 4.119 \\
\hline
\end{tabular}




\begin{tabular}{lccc}
\hline Malang & 4.898 & 4.736 & 9.634 \\
\hline Probolinggo & 2.458 & 2.438 & 4.896 \\
\hline Pasuruan & 2.018 & 2.109 & 4.127 \\
\hline Mojokerto & 1.589 & 1.650 & 3.239 \\
\hline Madiun & 2.384 & 2.819 & 5.203 \\
\hline Surabaya & 7.919 & 10.694 & 18.613 \\
\hline Batu & 2.067 & 2.039 & 4.106 \\
\hline $\begin{array}{l}\text { East Java } \\
\text { Province }\end{array}$ & 13.076 & 7.662 & 20.738 \\
\hline $\begin{array}{l}\text { Vertical } \\
\text { Institution }\end{array}$ & 43.473 & 28.262 & 71.735 \\
\hline East Java & 266.552 & 222.724 & 489.276 \\
\hline
\end{tabular}

division on State Civil Apparatus themselves and it will affect the service provided.

The Regional Election is not just a fiveyearly routine to give consent to make the turn of leadership, but it is a democratic means for people to maintain the continuity of a system that has been built. Thus, a continuity of development that can improve the degree of people's lives is born. Regional Election is also not just talking about the official figures that once powerful or political elites who have a huge libido to gain power, but an effort to determine the fate of the people in the next five years.

For the activeness of State Civil Apparatus in Surabaya City to become voters in any organization of Regional Election, although the vote in Regional Election is a right and not an obligation, but the entire State Civil Apparatus in Surabaya have always been active as voters in any Regional Election organization. This happens because every State Civil Apparatus certainly is very hopeful that the candidate pair of mayor and deputy mayor they are voting for will win in the Regional Election organization. In addition, the State Civil Apparatus hope for a significant impact for them if the winning candidate is their vote in the Regional Election, such as the effect on job placement in the "wet" field, get promoted to the higher position, and so on. The motivation to vote like these are certainly not good because it is not on the basis of full consciousness to be active as voters in order to use their rights as a good citizen.

For the participation of State Civil Apparatus in Surabaya City in disseminating and conveying information about Regional Election both in their family circle and the surrounding neighborhood, it is certain that the State Civil Apparatus in Surabaya participated in the dissemination and informing about the Regional Election both in their family circle, but the fact in the field shows that very few Civil State Apparatus that care to disseminate and convey the information about Regional Election in the neighborhood. They think that the information on the organization of the election is already known by the public through printed media, electronic media, the Regional Election Commission, the Election Supervisory Committee so that the State Civil Apparatus no longer need to socialize it.

For the participation of the State Civil Apparatus in Surabaya City as the campaigners for government to create a conducive atmosphere of Regional Election, in Surabaya City, a campaign to create a conducive atmosphere of Regional Election is carried out by members of the Regional Election Commission and the Election Supervisory Committee, so there is no State Civil Apparatus involved as the campaigners for that purpose. While in fact, ideally regional governments also need 
to do a campaign by involving several State Civil Apparatus as campaigners in order to assist the Regional Election Commission and the local Election Supervisory Committee.

For the participation of State Civil Apparatus in Surabaya City to become the members of PPK with a permission from their direct supervisors, there are some State Civil Apparatus in Surabaya City who take part in becoming the member of PPK (District Election Committee) with a permission of direct supervisor, namely State Civil Apparatus in Regional Election Commission of 2 personnel (Secretary and Head of Data Sub-Division). In addition, there are 3 more State Civil Apparatus assigned in PPK (1 Secretary, 1 Treasurer, and 1 on Technical Affairs) for each district ( $3 \times 31$ districts $=93$ personnel).

For the participation of State Civil Apparatus in Surabaya City as the members of PPS with a permission from their direct supervisors, there are also some State Civil Apparatus in Surabaya City who take part in becoming the member of PPS (Polling Committee) with a permission from their direct supervisors, namely 3 personnel of State Civil Apparatus X 154 urban-villages $=462$ personnel. For District Supervisory Committee, 2 personnel of State Civil Apparatus (District Supervisory Committee's Secretary and Treasurer) X 31 districts $=62$ personnel.

For the participation of State Civil Apparatus in Surabaya City as the members of KPPS with a permission from their direct supervisors, there are also State Civil Apparatus in Surabaya City who take part in becoming the member of KPPS (Committee Commission on Vote Election) with a permission from their direct supervisors, which is only for Election Supervisory Committee at the city level of 4 personnel (1 Secretary, 1 Treasurer, and 2 Staffs).

For the participation of State Civil Apparatus in Surabaya City who are also supporting the secretariat of Regional Election Supervisory Committee to organize the stages of Regional Election, there are also State Civil Apparatus in Surabaya City who are also supporting the secretariat of Regional Election Supervisory Committee to organize the stages of Regional Election, which is in accordance only with the structure of Regional Election Supervisory Committee (2 personnel).

For the participation of State Civil Apparatus in Surabaya City who are also supporting the secretariat of District Election Committee to organize the stages of Regional Election, there are also State Civil Apparatus in Surabaya City who are also supporting the secretariat of District Election Committee to organize the stages of Regional Election, namely the assisting State Civil Apparatus for the management of finance, 2 personnel for each Sub-district.

For the participation of State Civil Apparatus in Surabaya City who are also supporting the secretariat of Polling Committee to organize the stages of Regional Election, there are also State Civil Apparatus in Surabaya City who are also supporting the secretariat of Polling Committee to organize the stages of Regional Election, namely the State Civil Apparatus chosen by the community (averagely 3 personnel for each Sub-district).

\section{The Neutrality of State Civil Apparatus in Regional Election in Surabaya City}

The description about the neutrality of State Civil Apparatus in Regional Election in Surabaya City is also entirely obtained through interviews as described below.

For the partiality of State Civil Apparatus in Surabaya City towards one of the groups/classes, openly there is no State Civil Apparatus in Surabaya City who are sided and biased towards one of the groups/classes, for example, partial towards the group of supporters of certain candidates for mayor and vice mayor. However, a growing issue in the community showed that there are some State Civil Apparatus who are siding with the supporting group of a certain candidate pair of mayor and deputy mayor considered better suited to lead Surabaya City. It is indeed difficult to prove because it is not done openly by certain State Civil Apparatus. The lack of courage of State Civil Apparatus in siding with certain groups/classes openly is because of the ban and sanctions as stipulated in Law No. 5 of 2014 on State Civil Apparatus, Government Regulation No. 37 of 2004 on the prohibition of Civil Servants to become the members of political parties, as well as Government Regulation No. 53 of 2010 in the discipline of Civil Servants.

Deeds or actions that can be considered in violation of the neutrality of State Civil Apparatus and can be sentenced to moderate disciplinary penalty is to provide support to candidates for regional head/deputy head of the region by engaging in campaign activities in support of such candidates and conduct activities that lead to bias against candidates who will be participating in the Regional Election before, during, and after the campaign that include meetings, solicitation, appeal, instruction, or the provision of goods to the State Civil Apparatus within the work unit, family members, and the community. The penalty is either: (a) delay in salary increase, periodically for one year, (b) delay in promotion for one year, and (c) demotion to a level lower for one year.

Deeds or actions that can be considered in violation of the neutrality of State Civil Apparatus and can be sentenced to severe disciplinary penalty is to provide support to candidates for regional head/deputy head of the region, by using the facilities associated with a position in the campaign 
and/or make decisions and/or actions to favor or disfavor one candidate during the campaign period. The penalty is either: (a) demotion to a lower level for 3 years, (b) transfer in order of decreasing the rank a level lower, (c) exemption from office, (d) dismissal with respect not by his own request as State Civil Apparatus, and (e) dismissal without respect as State Civil Apparatus.

It is indeed interesting to assess the organization of the Regional Election in Surabaya City on December 9, 2015, as one of the regional head candidates is incumbent ( a pair of RismaWhisnu). The Election Supervisory Agency is in cooperation with the Ministry of Home Affairs (MOHA) and Ministry of Administrative and Bureaucratic Reforms (Kemenpan-RB) to safeguard the neutrality of civil servants in 2015 Regional Elections. Kemenpan-RB proposed that a joint task force is formed with the Ministry of Home Affairs to enforce the law for civil servants who are not neutral ahead of this 2015 Regional Elections. The task force is the door that facilitates the Election Supervisory Agency to supervise. The similar idea is supported by Director General of Politics and Public Administration of MOHA that MOHA will see the extent of Civil Servants' involvement on the successful incumbent. In this case, the Ministry of Home Affairs will not hesitate to impose sanctions if the involvement of Civil Servants is supported by valid facts and evidence.

For discriminatory actions by State Civil Apparatus in Surabaya City in selecting candidates for regional head/mayor, and since the selection of the Regional Election is organized with confidentiality, it is difficult to detect exactly which State Civil Apparatus who is discriminatory and which State Civil Apparatus who is not in choosing a pair of candidates for mayor/deputy mayor of Surabaya. However, if observed from the discussions surrounding the State Civil Apparatus on the Regional Elections, there are still some State Civil Apparatus who choose regional head candidates based on the considerations of gender, religion, ethnicity, closeness to the prospective regional head, or because of kinship. This is certainly less positive for selecting the regional head candidates since it is not based on competence, capability and credibility owned by regional head candidates.

For the sterilization of State Civil Apparatus in Surabaya City from group interest, there is no guarantee that the entire State Civil Apparatus in Surabaya City are sterile from group interest. Although with the naked eye the State Civil Apparatus' attitude looks sterile, but covertly it could be that a person of State Civil Apparatus is influenced by a group interest, namely the group interest of the supporters of certain regional head candidates. This State Civil Apparatus certainly does not support the government's policy on the neutrality of State Civil Apparatus in the Regional Election.

For the influence of State Civil Apparatus in Surabaya City from the interest of political parties, although State Civil Apparatus shall not be members of political parties, but the facts in the fields show that the State Civil Apparatus in Surabaya City often discuss or debate which political party is considered good and which is not considered good. The tendency of State Civil Apparatus to choose specific regional head candidates will also depend on which political party that became the supporter of regional head candidates.

For the abuse of authority owned by State Civil Apparatus in Surabaya City to help one of the regional head candidates in the Regional Election, given the sanctions that will be given to the State Civil Apparatus, then there is no State Civil Apparatus in Surabaya City who dare to abuse the authority owned to help one particular regional head candidates in the Regional Election in Surabaya City. This means that the existence of rules concerning the neutrality of the Civil State Apparatus in the election is quite effective to anticipate the State Civil Apparatus' violations in the organization of the Regional Election in Surabaya City.

For the use of state property by State Civil Apparatus in Surabaya City to help one of the regional head candidates in the Regional Election, and also given the sanctions to be given to the State Civil Apparatus, then there is also no State Civil Apparatus who dare to use state property to help any particular regional head candidates in the Regional Election in Surabaya City.

\section{Factors Affecting the Participation and the Neutrality of State Civil Apparatus in Regional Election in Surabaya City.}

Based on the interview, there are three (3) main factors affecting the participation of State Civil Apparatus in the Regional Election in Surabaya City. First, the leadership exemplary factor. If all leaders in every Regional Work Unit (SKPD) in Surabaya City provide good exemplary, which is to always be active as voters in any organization of Regional Elections, then it is very likely that all subordinates follow the example of the leaders.

Second, the State Civil Apparatus' commitment factor. If every State Civil Apparatus in Surabaya City has high commitment to implement all policies that have been set by the central government and local government, including policies of the importance of the participation of State Civil Apparatus in the organization of Regional Election, then the State Civil Apparatus will always be neutral to political parties, always active as voters in every organization of Regional Election, take part in the 
dissemination and the delivery of information on Regional Elections, both within the family and the surrounding neighborhood, and participate as the government's campaigners to create a conducive atmosphere of Regional Elections.

Third, State Civil Apparatus' development factor. Intensive coaching to the State Civil Apparatus on the importance of creating conducive political condition and produce qualified political leaders (regional heads) can lead to increased awareness of State Civil Apparatus to participate in the organization of the Regional Election in Surabaya City, such as: participate as the members of PPK, participate as the members of PPS, participate as the members of KPPS, support the Election Commission secretariat to implement the stages of Regional Election, support the PPK secretariat to implement the stages of Regional Election, and support the secretariat in PPS to implement the stages of Regional Election in Surabaya City.

Furthermore, there are two (2) principal factors that affect the neutrality of the State Civil Apparatus in the Regional Election in Surabaya City. First, internal factors (originating from inside the Civil Servants), which are the individual factors of the actors themselves (State Civil Apparatus) to favor one of the regional head candidates or one of the political parties, namely: (1) the factor of ambition of the State Civil Apparatus to obtain a certain position, in which with the favor towards certain regional head candidate, will be obtained a reward in the form of position that would be occupied if the supported candidate win in the Regional Election; and (2) the factor of primordialism in the form of kinship, customs, regional, material interests, ethnicity, and the like which also influence whether or not State Civil Apparatus is neutral in the Regional Election in Surabaya City. The example of case related to customs relation in Surabaya City, the current trending method utilized by regional head candidates to attract sympathizers is through the customary meetings. Usually, from his native clan or his mate clan will be held gatherings, can be in the form of social gathering or celebrating Christmas together.

Second, external factors (originating from outside of the Civil Servants), namely: (1) working environment actors of State Civil Apparatus. As is the characteristic of bureaucracy proposed by Asmerom and Reis, then the characteristics of a neutral bureaucracy will be seen from whether a government institution applies the merit system or not. Related to the merit system, it is still difficult to implement a merit system in the bureaucracy in Indonesia. If it is associated with the opinion of Weber stating that the concept of ideal bureaucracy is characterized by the condition where one of the positions in the bureaucracy is filled by a person who is technically competent or professional and employees view the task as a life career, then the designation of regional head as the career builder for Civil Servants will result the perspective of State Civil Apparatus towards the loyalty to the regional area becomes bigger. It is because the State Civil Apparatus will view that their career will depend heavily on the regional head, as well as a perception that any person appointed as the regional head to occupy a position will attach a status of professionalism from these employees. Thus, even if the Law No. 23 of 2014 states that the career development of State Civil Apparatus considers integrity and morality, education and training, promotion, transfer between office, transfer between regions, and competence, but with the guidance given to the regional head who is a political person, then the dependence of State Civil Apparatus to politicians will be very large. Therefore, Civil Servants will be difficult to maintain neutrality; (2) regulatory factors which do not support the creation of good supervision by the public. For example, the limitation period of 3 days to file complaints/reports from the public makes some cases of violation of the Civil State Apparatus in the Regional Election in Surabaya City, which has been reported can not be processed because the time of the incident has passed the statutory provisions. It must be admitted that Indonesian society's level of awareness is still low in reporting/filing a complaint. This could be due to poor education and also the high level of indifference. The low level of education resulted in people not knowing what is right and what is wrong. And this level of ignorance leads people to think indifferently to the event that happened surround them as long as it does not provide direct losses to them. Likewise, the difficulty of getting witnesses (minimum 2 persons) and other evidence (photographs or recordings) which must be submitted together with the reports/complaints. It is certainly more difficult for people to be able to play an active role to supervise the activities of State Civil Apparatus in Surabaya City. As a result appears apathy towards the conduct of State Civil Apparatus in Surabaya City. In such society situation, the role of the actual monitoring agency should be able to play these missing roles; (3) factor of provocation or even a threat to the State Civil Apparatus by the leaders or the people who are assigned by the leaders to instruct State Civil Apparatus to favor certain regional head candidates. For example, the threat of being transferred or removed from their post if not choosing specific regional head candidates; (4) factor of the promises given by a person or a group of persons to the State Civil Apparatus when choosing a particular regional head candidates. For example, a promise to be promoted at a particular position if certain regional head candidates win in 
the organization of the Regional Election; and (5) the factor of weak supervision from the authorities to the State Civil Apparatus for violating the rules on State Civil Apparatus' neutrality in Regional election, including the lack of decisiveness on the imposition of sanctions against violations committed by State Civil Apparatus.

\section{E. The Policy to Improve the Participation and to Keep the Neutrality of State Civil Apparatus in the Organization of Regional Election in Surabaya City}

According to the result of FGD, there are at least 3 (three) policies that need to be implemented to increase the participation of State Civil Apparatus in the organization of Regional Election in Surabaya City. First, strongly prohibiting political intervention from the leader. It because, with the existence of political intervention from the leader will make the voting participation level of State Civil Apparatus be low. It could be that because of the intervention, the State Civil Apparatus are being reluctant to vote. Therefore, the relevant parties such as Regional KPU and Regional National and Political Unity are expected to provide guidance to State Civil Apparatus about the importance to vote on Regional Election.

Second, improving the image of State Civil Apparatus's professionalism. The role and function of State Civil Apparatus are very potent in elections. State Civil Apparatus must active as the voters and provide socialization programs to families and neighborhoods about the election. State Civil Apparatus activeness is needed to give confidence about the importance of Regional election to the public so as to reduce the number of abstentions.

Then, the State Civil Apparatus should be the government's campaigners to tell the community about the policies of Regional KPU and various state's policies in improving knowledge and building active community participation in the election. Then, the active participation of State Civil Apparatus can be realized by not being a partisan of political parties/candidates in Regional Elections and the implementation of governance and professional action in carrying out their duties.

State Civil Apparatus's active participation is also required to support the Regional KPU'S secretariat to implement various stages of Regional Elections. As the supporting staff of the Election Commission, State Civil Apparatus's professionalism will greatly determine the success of each stage, ranging from dissemination, distribution of ballot papers and ballot boxes, and determining the winner. The active involvement State Civil Apparatus to become the members of PPK, PPS, and KPPS is very possible in accordance with Article 41 of Law No. $10 / 2008$, given the limitations of the population who are eligible to be the members of the election committee.

However, the neutrality and professionalism of the civil servants must be maintained, especially as the members of the election committee that will greatly determine the success of the election. State Civil Apparatus in succeeding the Regional Election will increase public confidence in the neutrality of civil servants.

Therefore, the Regional Election is a momentum for State Civil Apparatus to improve the image of professionalism and neutrality of civil servants as well as to gain the trust of the community. Moreover, the exemplary of the State Civil Apparatus to persuade people to use their voting rights at the Regional Election is very important, so that the democratic process could run better. State Civil Apparatus also has a major role in maintaining security and conditions in the region or in the environment to always be conducive from various differences in the election.

Third, create State Civil Apparatus's exemplary. The employees have great potential to invite people in the neighborhood to later use their voting rights. Thus, any State Civil Apparatus should be an example for the people in using their rights to vote, and not to abstain. As public servants, State Civil Apparatus have an obligation to succeed the General Election to be able to run safely, peacefully, and with quality. It is expected that by deploying the entire State Civil Apparatus to invite the community to participate using their voting rights, the concern about the high number of abstentions can be prevented. Each regional head needs to instruct all their State Civil Apparatus to invite people in each neighborhood, to come to the provided polling stations, and to vote as well as possible.

Furthermore, based on the results of the interview, there are some policies that need to be done to maintain the neutrality of the State Civil Apparatus in the organization of the Regional Election in Surabaya City. First, to create a neutral bureaucracy in the organization of the Regional Election needed a support to change the laws and regulations. Related to the changed legislation material relevant to with Regional Election, it is important to limit the time in order to create legal certainty. Even so, the reporting period must be extended from three (3) working days to seven (7) working days. This is considering the distance between the location of the event and the location of Election Supervisory Committee which is usually in remote areas and is also an opportunity for the complainant to collect the evidence needed.

Second, changes to the career development material of regional employees from the head of the region as a political officer to the officials with the highest career in the region. Given that the loyalty of 
bureaucrats will depend heavily on a boss who will influence the decision on the career. Changes to the rules only on the election sector will not be effective to change the behavior of the bureaucrats.

Third, change the regulation of the Regional Trustees Personnel Officers who have the authority to set the assignment, transfer, and dismissal of the State Civil Apparatus to be delegated to the Regional Secretary. Thus is intended to avoid regulation ambiguity. The regional head is the political official who can not intervene against employment policy that will affect the position of State Civil Apparatus.

Fourth, carrying out the responsibilities of Trustees Personnel Officer in the region, namely: Disseminating about the neutrality of State Civil Apparatus in the Regional Election; Checking and supervising the implementation of the neutrality of the State Civil Apparatus in the Regional Election; and Imposing penalties to State Civil Apparatus if on their community, there is someone who violated the neutrality of the State Civil Apparatus.

Fifth, strengthen institutional structures and the neutrality violation of civil servants in the election by creating a functional workstructural relationship of Election Supervisory Agency, Election Supervisory Committee, BKD, and Regional Inspectorate. The institution that governs the type of violation is BKD and Inspectorate, the institution that recommends violations that have been committed by State Civil Apparatus is Election Supervisory Committee, the institution that founds the violations committed by State Civil Apparatus is Election Supervisory Committee, BKD, and the Inspectorate, and the institutions that impose the sanctions are mayors/regents/governor. In addition to this institutional structure, Standard Operating Procedures (SOP) is also required to clarify the authorities of each of the institutions so that there is clarity in the enforcement of sanctions.

Sixth, strengthen the society supervision of aspect of. To improve the supervision of society itself from the behavior of the bureaucracy, it is important also to provide insight into the importance of public scrutiny of the community itself. Without this, the Election Supervisory Committee manpower, which only consist of 3 personnel, would be very unlikely to do this effectively. For supervision, the public should also be given legal power assistance which can help them to provide a report in case of misconduct of the government apparatus. This certainly requires time and cost. The assistance of NGOs in the near future is indeed very meaningful.

Seventh, providing a deeper understanding to the bureaucrats (State Civil Apparatus) about their duty as government administration apparatus. Thus, all the reasons that are sought thus far to cover the activities of their non-neutrality can be eliminated. Likewise, the release of double positions of state administration officials from the position as board of political parties should be implemented strictly. Without this, the rules made are going to be in vain because there is always a person who will look for loopholes to break them.

\section{Conclusion}

In general, the participation of State Civil Apparatus in Regional Election in Surabaya City is quite good, which was showed by the activeness of State Civil Apparatus to be the voters on each Regional Election. State Civil Apparatus also took part in disseminating and conveying the information about Regional Elections in their family circle (although in their residential area, they are less concerned), State Civil Apparatus also became the member of PPK, PPS, KPPS, and State Civil Apparatus also supported the administration in Regional KPU, in PPK, and in PPS to implement the stages of Regional Elections.

However, the neutrality of State Civil Apparatus in the Regional Election of Surabaya City still has not run well, which was showed by the number of State Civil Apparatus who covertly take sides and siding with one of the groups/classes of Regional leader candidates, and also there is yet any guarantee that all State Civil Apparatus are free from groups' interest and influenced by the interest of political parties.

At least there are three main factors that affect the participation of State Civil Apparatus in Regional Elections in Surabaya City, namely (1) Leadership Exemplary factor, (2) State Civil Apparatus's commitment factor, and (3) State Civil Apparatus's development factor.

Then, there are at least two main factors that affect the neutrality of State Civil Apparatus in the Regional Election of Surabaya City, namely: (1) Internal factor (State Civil Apparatus's big ambition to get certain position, and primordialism factor in the form of kinship, custom, regionalism, material needs, tribalism, and so on; and two external factors (State Civil Apparatus's working environment, regulations that do not support the creation of good supervision by the community factor, provocation o even threat to State Civil Apparatus by leaders or people who are appointed by leaders to instruct State Civil Apparatus to choose certain regional leaders factor, promises given by someone or a group of people to State Civil Apparatus if the choose certain candidate factor, and the weak supervision of the authority to State Civil Apparatus that conduct the violation of rule on the neutrality of State Civil Apparatus in Regional Elections, including the less decisiveness on the implementation of sanctions for the violation committed by State Civil Apparatus factor). 


\section{REFERENCES}

Arfani, F. (2015). 26 pasangan daftar pilkada serentak di Jatim. Antaranews.com. Retrieved 28 July 2015, from http://www.antaranews. com/berita/509100/26-pasangan-daftarpilkada-serentak-di-jatim

Fischer, F. \& Sirianni, C. (2007). Critical Studies in Organization and Bureaucracy. Philadelphia: Temple University Press.

Government of Republic of Indonesia,. (2010). Government Regulation No. 53 of 2010 about Civil Servants' Discipline. Jakarta: Ministry of Law and Human Rights.

Government of Republic of Indonesia,. (2014). Law No. 5 of 2014 about State Civil Apparatus. Jakarta: Ministry of Law and Human Rights.

Henry, N. (2004). Administrasi Negara dan Masalahmasalah Publik. Jakarta: PT. Gramedia.

Jer, A. (2015). Tingkat Partisipasi PNS dalam Pemilu Sangat Rendah - Tribun Pekanbaru. Tribun Pekanbaru. Retrieved 21 September 2015, from http://pekanbaru.tribunnews. com/2015/09/21/tingkat-partisipasi-pnsdalam-pemilu-sangat-rendah

Kadir, J. (2010). Netralitas Birokrasi dalam Pemilihan Walikota dan Wakil Walikota Surabaya: Studi Kasus di KPUD Kota Surabaya (Master Thesis). Universitas Gadjah Mada.

Kuncoro, B. (2007). Netralitas Birokrasi dalam Pemilukada. Swara Politika, 10(1).

Pradhanawati, A. (2005). Pilkada Langsung, Tradisi Baru Demokrasi Lokal. Surakarta: KOMPIP.

Prasojo, E. (2005). Demokrasi di Negeri Mimpi: Catatan Kritis Terhadap Pemilu 2004 dan Good Governance. Jakarta: Departemen Ilmu Administrasi FISIP UI.

Purba, L. (2010). Netralitas PNS dalam Pilkada Secara Langsung: Studi Kasus Kabupaten
Malang, Kabupaten Gowa, dan Kabupaten Kukar (Master Thesis). Universitas Indonesia.

Riggs, F. (2008). The Modernization of a Bureaucratic Polity. Honolulu: East-West Center Press.

Ritan, S. (2005). Netralitas Birokrasi Dalam Pemilihan Kepala Daerah dan Wakil Kepala Daerah: Studi Kasus Pemerintah Kabupaten Flores Timur (Master Thesis). Universitas Gadjah Mada.

Rourke, F. (2009). Bureaucracy, Politics, and Public Policy. USA: Little Brown.

Santoso, E. (2015). Kelebihan \& Kekurangan Pilkada Serentak. Warta17agustus.com. Retrieved 17 March 2015, from http://warta17agustus. com/berita-kelebihan--kekurangan-pilkadaserentak-.html

Saputro, S. (2013). Partisipasi PNS dalam Pemilukada Pemalang. Jawa Timur: KPUD Pemalang.

Silaban, F. (2016). Dilema Netralitas PNS Masih Jadi Perdebatan / Badan Pengawas Pemilihan Umum Republik Indonesia. Bawaslu.go.id. Retrieved 20 May 2015, from http://www.bawaslu.go.id/ en/berita/dilema-netralitas-pns-masih-jadiperdebatan

Sriwahyuni, G. (2006). Netralitas PNS dalam Pilkada Secara Langsung: Studi Kasus di Kabupaten Tabanan (Master Thesis). Universitas Gadjah Mada.

Stoner, J. (2010). Manajemen. Jakarta: Erlangga.

Sutarto,. (2012). Dasar-dasar Organisasi. Yogyakarta: UGM Press.

Thoha, M. (2003). Birokrasi dan Politik di Indonesia. Jakarta: PT. Raja Grafindo.

Whitney, F. (2000). A Four Year Continuation Study of a Teachers College Class. New York: The Macmillan Co.

Yamin, M. (2012). Netralitas PNS dalam Pemilukada di Kabupaten Takalar (Undergraduate Thesis). Universitas Hasanuddin. 